\title{
The Ideal Law in Indonesian Pluralistic Society Based on Constructivism Paradigm
}

\author{
Aditya Yuli Sulistyawan \\ \{adityayuli38@gmail.com\} \\ Faculty of Law, Diponegoro University, Semarang, Indonesia
}

\begin{abstract}
Indonesia is an archipelago state which has many ethnics, religions, races, ethnicities, and cultures. This diversity shows there is plurality in Indonesia. Such diversity becomes a pride, but it also creates another problem. For example, regarding law issues, there are different treatments toward the citizens that shows the complexity of legal reality. Indonesia has law growth and development locally among its people, for example, customary law or other custom laws. Although law positivism matches the reality of the country's law, which is designed "top-down" and is deterministic and objective for anyone, there are vast imperfect differences in reality. There are many conflicts between the national law and local law, such as the domination of national law over the local law. There are two problems of this paper: First, how is the law in a plurality of Indonesian society reviewed from the paradigmatic study? Second, how is the ideal law in a plurality of Indonesian society based on Constructivism Paradigm? In this paper, the writer was guided by constructivism paradigm by using hermeneutics/dialectic method. The explanation of the Indonesian plural society and the law would be studied paradigmatically. The analysis of this discussion would lead to the answer of necessary "bottom-up" law design through constructivism paradigm, which will deliver harmony in diversity, with a law that is more humanistic and democratic.
\end{abstract}

Keywords: plural; paradigm; constructivism; local law

\section{Introduction}

Indonesia is a country with citizens coming from various backgrounds. The diversity of ethnics, religions, race, ethnicities, and culture of Indonesians is a priceless wealth. The union of these diversities is commonly called as "Nusantara." Indonesia's archipelago with its thousands of islands makes such plurality noticeable with the different culture products, customs, and traditions. Thus, Indonesia is also known as the country that has various customs in each area.

The diversity of customs, races, religions, ethnicities, and culture of Indonesians deliver many typical habits in its local citizens. The customs include how the people overcome their problems in their daily life, which we mention as the customary law. Adat law is a kind of "Indonesian customary law."However, the matter is not as clear and distinct as that. Adat in Indonesian context always comes with an attribution; it can be adat Sunda, adat Jawa, adat Aceh, adat Minangkabau, adat Sulawesi, etc. There is no such thing called adat Indonesia [12].

It is an undeniable fact that the role of local law is significant in solving the problems in society. Such law has communal traits, and it came from the philosophy of people's lives which puts forward the balance between humans and nature. Local law also emphasizes the purpose of harmony, suitability, and conformity toward fulfillment of justice and discipline in society. As a community, adat law community has its typical rights and obligations to perform both individual and social rights as well as personal and social obligations [16].

However, in reality, the customary law appears to be a problem because the country law 
requires its validity and objectivity. The existence of national law in the social setting, especially in that of local people, often becomes the burden for the receivers. The law and local culture are not always compatible. The law as a modern formal system which has been designed centrally (national)contrasts with the informal local culture. Both laws are not only social construction of different "worlds," but they also have different "basic concerns."

Admittedly, the national law design which pivots to codification politic and unification has succeeded to construct the modern law. We have written legislation which is rationally managed. We also have a modern judiciary which is maintained by educated professionals, especially those who operate the law codification. National law system has its problems. Some of them are at praxis level, especially in the context of the local community with a unique plurality.

In the perspective of traditional criminal law, customary law is ignored, and it exists marginally. The principle of legality requires the exclusion of customary law. The real status and function of customary law in judicial practice attracts little attention in academic circles, and it escapes the attention of the lawmakers. However, in every country, customary law's status in theory and legislation is not necessarily equivalent to its real status in judicial practice, which possibly signifies some discrepancy and paradox. (2)

National law determination over the local law has finally become a reality. One of the examples of the cases is in 2009, the battle between AnakDalam ethnics who lived in DuaBelas National Park Hill Jambi that caused the death of three people. Both parties had solved the problem by using the customary law of the jungle, which is usually known as Kubu ethnic. However, a problem appeared when the police also had processed this case through the country's law. The ethnic of AnakDalamwas furious with the country's law intervention. There was an anarchist demonstration in front of the Sarolangun District Court. It became their choice to oversee the country'slaw. (3)

The conflict of law enforcement above can be explained theoretically. However, the paper aims to deliver an analysis of the case on a paradigmatic level by pointing out the order ontologically, empirically, and methodologically. These steps will deliver a comprehensive understanding of observing the reality of law - it also shows the originality of this paper compared to the other previous researches. Furthermore, the purpose of this paper is to understand the many reality of the law in Indonesia in the paradigmatic study. It also aims to show what kind of ideal law fits the plural Indonesian society.

\section{Methodology}

Based on the paradigm idea of Guba and Lincoln, the writer used the constructivism paradigm approach in this paper. Relativism is the answer to the questions of the ontology of constructivism paradigm. Epistemologically, this paradigm was transactional/ subjective. The writer also used the hermeneutical/ dialectical method to match the constructivism paradigm that was used to elaborate on the plurality of Indonesian law. (4)

The technique of collecting the data was the literature review. The result of the literature review would be analyzed by using qualitative analysis. Qualitative tradition emphasized the reality which is developed socially, as well as the relation between the researcher, the subject, and the obstacles that shaped the research. (5)

Based on the above explanation, the qualitative tradition used in this research is done as an effort to understand the problems in this research in-depth, which results in a descriptive explanation from the observation of the researcher on the research problems. 


\section{Findings}

\subsection{Law in the Plural Indonesian Society}

In Indonesia, potential friction between local law and national law is quite high. The local law that has been established as developed from the local psychological atmosphere which emphasizes plurality. On the other hand, the law made by the country tends to demand uniformity of the legal order. How is the presence of the country law which is "top-down" among the plural Indonesian society?

At least, the presence of country law in the local context will deliver two cases: First, as the consequences of centralized regulation, not all of the policies, procedures, and mechanisms are known to the broader Indonesian people. Second, law development tends to focus on how to make more regulations without thoughtful consideration about society's conditions and the impacts of the regulations itself. Under the 'charter' of national law, ethnics of the nation which are spread from the Sabang to Merauke, are "pulled" in a room of 'uniformity' law. (1)

In the name of uniformity, generalization is conducted. Civil law has to reduce the complex social facts finally. About this uniformity, Montesquieu ever stated -as if- sued, "There are certain ideas about uniformity that tie the big souls,... but it must break the small ones. .... is not that genius greatness in the ability to know in whether it needs uniformity or diversity?". It seems like we agree that Montesquieu's words are related to legal reality in this country, in the name of certainty, the written law changes local order and the support of institutions. In the name of codification, pennants of written regulation are designed as the flag in national law. For the unification, law codificationisassumed as the only legal system without legitimation and local wisdom.

Admittedly, formal legal order enjoys the legality of monopoly, including the power to use coercion legally. However, it does not mean anything that automatically it has the truth of monopoly and social significance. Formal law order cannot be revealed having a kind of monopoly toward social obedience in society. (1)The existing adat law and social morality become the primary source of law. Hooker states that indigenous dispute resolution should be based on adat values such as the value of togetherness, the value of totality, and the value of appropriateness. By contrast, the formal court is based on an objective pre-existing legal source which is a legal proposition stipulated by legislators and applied by judges [8].

In the plural Indonesian society, local law has played a significant role in creating harmony. Every problem among its people is always returned to the values and norms existing in the community as the guidance to solve their problems. The typical problem handling creates a discipline that makes harmony and life balance among the people. Federal law usually disturbs and demands to be implemented when law-related problems arise. The presence of formal law disturbs the harmony so that it presents the question "if discipline and harmony do exist, so why local law has to be implemented if it makes more problems?"

Paradigmatic study becomes the choice for the writers to explain and decrease the problems wisely. The understanding of the implementation of country law or local law among plural Indonesian society can be explained in the paradigmatic study through paradigm understanding which was explained by Guba and Lincoln.

Of the many experts who try to offer the following understanding of paradigm classification, the authors tend to adopt the opinions of Guba and Lincoln which, according to ErlynIndarti, are more encompassing as well as systematic, reliable, and rational. They primarily lean more towards the global notion of the paradigm, distinguishing paradigms based on their answers to 3 (three) 'basic questions' concerning: 
- the shape and nature of reality, and what can be known about it [referred to as 'ontological' questions];

- the nature of relationships or relationships between individuals or groups of people with the environment or everything outside of themselves, including what can be known about it [referred to as 'epistemological' questions, into which includes 'axiological' questions]; and

- the way in which individuals or community groups [including researchers, of course] get the answer to what they want to know [is called a 'methodological' question] [10].

It is essential to have a firm understanding of these elements because they comprise the underlying assumptions, beliefs, norms, and values that each paradigm holds [11].

Before discussing that, paradigm here is explained as the central philosophy which includes ontology, epistemology and other specific methodology, which consist of a set of fundamental beliefs or worldviews that do not readily change (with fundamental beliefs or worldviews from ontology, epistemology, and another paradigm methodology). Paradigm represents a system of certain fundamental beliefs related to main or first principles, which ties the believer/user on particular worldviews. (4)

The paradigm consists of combined fundamental beliefs which guide the way/action of the paradigm believer. In the context of fundamental belief, Guba and Lincoln identify that there are four main paradigms in social reality which guide the believer in ontology, epistemology, and methodology in understanding the world. They are positivism paradigm, post-positivism, critical theory, and constructivism. Guba and Lincoln have disclosed an incredibly helpful contribution to articulating and distinguishingopposing paradigms of investigation [7].

These are four main paradigms in social science, including law science, according to Guba and Lincoln [10].

TABLE 1. BASIC BELIEFS OF PARADIGM

\begin{tabular}{|c|c|c|c|c|}
\hline & Positivism & Post-positivism & $\begin{array}{c}\text { Critical } \\
\text { Theory et al. }\end{array}$ & m Constructivis \\
\hline Ontology & $\begin{array}{l}\text { naive realism - } \\
\text { "real" reality but } \\
\text { apprehend-able }\end{array}$ & $\begin{array}{l}\text { critical realism - } \\
\text { "real" reality but } \\
\text { only imperfectly } \\
\text { and } \\
\text { probabilistically } \\
\text { apprehend-able }\end{array}$ & \begin{tabular}{l}
\multicolumn{2}{c}{ historical } \\
realism - \\
virtual reality \\
shaped by \\
social, \\
political, \\
cultural, \\
economic, \\
ethnic, and \\
gender \\
values; \\
crystallized \\
over time
\end{tabular} & $\begin{array}{l}\quad \text { relativism - } \\
\text { local and specific } \\
\text { constructed } \\
\text { realities }\end{array}$ \\
\hline $\begin{array}{l}\text { Epistemol } \\
\text { ogy }\end{array}$ & $\begin{array}{l}\text { dualist/objectivi } \\
\text { st; findings true }\end{array}$ & $\begin{array}{l}\quad \text { modified } \\
\text { dualist/objectivist; } \\
\text { critical } \\
\text { tradition/communit } \\
\text { y; findings probably }\end{array}$ & $\begin{array}{l}\text { transactio } \\
\mathrm{n}- \\
\text { al/subjective- } \\
\text { ist; value } \\
\text { mediated }\end{array}$ & $\begin{array}{l}\text { transaction- } \\
\text { al/subjective-ist; } \\
\text { created findings }\end{array}$ \\
\hline
\end{tabular}




\begin{tabular}{|c|c|c|c|c|}
\hline & & true & findings & \\
\hline $\begin{array}{l}\text { Methodol } \\
\text { ogy }\end{array}$ & $\begin{array}{l}\text { experimental/ma } \\
\text { nipulative; }\end{array}$ & $\begin{array}{c}\text { modified } \\
\text { experimental/manip }\end{array}$ & $\begin{array}{l}\text { dialogic/d } \\
\text { ialectical }\end{array}$ & $\begin{array}{l}\text { Hermeneutical/ } \\
\text { dialectical }\end{array}$ \\
\hline & $\begin{array}{l}\text { verification } \\
\text { hypotheses; chiefly } \\
\text { quantitative } \\
\text { methods }\end{array}$ & $\begin{array}{lr}\text { ulative; critical } \\
\text { multiple; } \\
\text { falsification } \\
\text { hypotheses; } \\
\text { include qualitative } \\
\text { methods }\end{array}$ & & \\
\hline
\end{tabular}

The four paradigms that live along the world have shown its existence in various social realities, for example, in legal life. Legal life is the application of paradigms which guides its believer. Country law and local law that live within a social environment are also embodiments of the fundamental beliefs to the real world from different two paradigms.

The implementation of country law with a law system in the paradigmatic study shows application from positivism paradigm. Law country which puts forward the uniformity has the characteristics according to positivism paradigm ontology which is naive realism. Law, in this case, is explained as an external reality, real objective and deterministic.(4)

Thus, it can be known that written country law breaks through each space and time, making the law to have single meaning only, is objective, and can be forced to all people without exception. Typical local aspects are ruled out due to its uniformity to create specific law. The implementation does not depend on the will of person per person or group per group, but it applies to the public beyond the groups' uniqueness. Without considering the structural difficulty that has been felt by the people, the country implements the law for law fiction. The people are blindly assumed to obey the law after it is written in-state institution.

The law that is run this way is in line with Hans Kelsen's ideas. Kelsen's monistic and logical approach is so well known as not to require lengthy explanation. Its essential elements are: i) the identification of law and state; ii) the idea that a legal order is a compound of norms, the validity of which relies on a hypothetical basic norm, the Grundnorm; ill) the exclusion of any factual element in the construction of a legal order; and iv) the repudiation of any reference to other non-logical premises, such as morals or natural law.(6)

Paradigm study through epistemology aspect shows that the country/nation law and the common law of Indonesia have dualism/objective, which implies that they are not related to each other. Country law has to be objective, impartial, and free of value and bias. It will guarantee that there is objectivity that becomes the validity of the truth and reality. Positivists go forth into the world impartially, discovering absolute knowledge about an objective reality [15].

Methodologically speaking, country law is implemented in the 'experimental/manipulative' way in the empire test. In short, the law is implemented by matching the written text case reality in a syllogism. By implementing this kind of law, the truth verification is based on law reality that forms the rule texts. The role of context in the meaning of each reality becomes irrelevant.

Country law is different from national law in which it represents the positivism paradigm, while local law comes from a particular society which represents non-positivism paradigm. This case is constructivism paradigm. Thus, it is understood that national law and local law are different, since both of them come from two different paradigms, and have typical in ontology, epistemology, and each methodology.

The local law, including customary law, is reality law which is ontologically relative as 
constructivism paradigm ontology. This kind of law is plural and diverse in reality, based on social-individual, local and specific. It is mental construction/human intellectuality, form, and content of believer can change become informed and sophisticated, humanity. (4)Constructivism holds that truth is a particular belief system held in a particular context. Like critical theory, constructivism inquires about the ideologies and values that lie behind a finding so that reality consists of "multiple realities" that people have in their minds [9].

From that ontology, it can be concluded that local law is the law that is contextual and established from local society's soul. Local law is formed through consensus of society's community. Local situation context determines the strategy of discipline. Value, norm, and gathering of society are variables which relate to local discipline construction. The unique structure of community will color discipline construction uniqueness they belong to. It will be challenging to measure in a set of discipline from the outside.

Ontologically, local law which is guided by constructivism paradigm is contextual according to local society. Thus, local law in each area is not the same because justice is not created the same for the plural Indonesians.

Meanwhile, local law epistemology and law society are subjective, which mean there is a subjective attachment that individual interpretation and understanding also determine the law. In this case, the law is established by the subjective understanding of the user so that it implements the subjunctive will. It makes local law assimilate with the local values and is respected by the community.

Whereas in methodology, local law is implemented in 'hermeneutic/dialectical' in which people interaction (with the understanding) through the dialectical process will determine how the law works. Local law is created based on the agreement of the members through the dialectic process, and it is run with the interpretation of the members. This kind of law is flexible according to the needs, as it does not grip like nation law. If there is a new problem, interpretation is needed to establish a new agreement as the law applied among them.

There is a paradigm study toward nation legal reality and local law which shows that both laws are made from different sets of fundamental beliefs. If both law realities are understood well through paradigm analysis, the conflict between these laws will not happen. It is because every paradigm has each truth which cannot be compared to other paradigm truth. Set fundamental beliefs in this paradigm context are 'the outlines of belief over truth' for the believer.

Thus, law implementation is paradigm operating from person to person which implements the law. If the individual uses the law guided by the positivism paradigm, the nation law implementation is the only choice. Meanwhile, for those who are guided by constructivism paradigm, the local law that holds agreement becomes the leading choice. Its implementation over each law cannot be debated because the laws are right in each paradigm.

\subsection{The Ideal Law in Indonesian Pluralistic Society Based on Constructivism Paradigm}

Based on the paradigm study, which has been explained above, an ideal law among the plural Indonesians is the constructivism paradigm law. The plural operational space of Indonesian society makes it unable to create the same law reality as that of the national law. In contrast, the plurality of the Indonesians and local laws are the ideal choices to implement the law.

However, constructivism paradigm law as a local law which comes from diversity can be implemented in written form like the national ones. In other words, national law does not always come from the positivist paradigm, as it can come from constructivism paradigm. The 
national law which comes from constructivism paradigm is an ideal law among the pluralistic Indonesian society.

However, the question of what national law model is constructed from constructivism paradigm might arise. The federal law which is made by the country at first must accommodate local society's values. Each process of making national law should involve all stakeholders, including the marginalized society. The written law should be written in a general context. The specific matters will be then explained contextually by the rules applied in each flat area. In this way, the local uniqueness will bridge contextual, humanity, and democratic rule through the local law.

Therefore, national law is 'top-down,' and the local law does not need to be opposed. Both laws can be implemented in harmony in law enforcement if the national law is made democratically in constructivism paradigm. Once it is conducted, the 'bottom-up' law will happen, and it can contextually deliver justice because it accommodates the local values and culture of the society.

In the level of positive law enforcement, the ideal law among plural society puts forward the judge the role of constructivism paradigm. The same thing is accommodated through the guarantee of the implementation of the independent judicial power, based on article 5 Verse (1) Constitution Number 48 in 2009. Judge and judge of the constitution must represent, follow, and understand law values and justice which live in society.

In examining and determining the charges, judges face the real situation that written law is not always able to solve the problem. The judges usually try to find rechtsvinding themselves and create the law of rechtsscheppingto complete the existing laws in determining the charges. The judge himself has to find the law. Through the determinations of the judge, it does not determine which in constitution texts (judge as funnel law) but he/she also does renewal law when there are problems which have not been regulated in the constitution, or it has been made, but it is irrelevant with the condition (judge-made law).

Constructivism paradigm judge who is based on real law is a too subjective belief in the frame of mental construction. In other words, we call it 'conscience.' The existence of conscience in using law makes the law is not as rigid as the written law, but also it looks at the law as an empiric reality in the society. Thus, the judge can make the law based on conscience in understanding the problem contextually.

\section{Conclusion}

The conflict of enforceability of local law and national law in the pluralistic Indonesian society can be understood in the paradigmatic study. The national law made by the state, which is "top-down" in nature is the product of thoughts guided by the paradigm of positivism. Meanwhile, local laws which are contextual depart from the paradigm of constructivism that is characterized by relative reality, local and specific.

The ideal law amid a plural society is the law guided by the paradigm of constructivism. The law in question is a law that was born as a consensus of the local community, as well as the democratically constituted state law, arranged in such a way as to be generalized as an "umbrella" for subordinate local regulations that allows the local and specific arrangements. This legal model is "bottom-up," accommodating the wishes of local people for the sake of the realization of justice for all parties. 


\section{References}

[1] B. L. Tanya, Hukum Dalam Ruang Sosial. Yogyakarta: Genta Publishing; 2010.

[2] D. Yu, "Customary Law in The Practice of Criminal Law: A Real and Powerful Role," Peking Univ Law J, 36, 2013.

[3] E. Indarti, Diskresi dan Paradigma : Suatu Telaah Filsafat Hukum. Semarang: Badan Penerbit Undip; 2010.

[4] N. K. Denzin, The Sage Handbook of Qualitative Research 1. 3rd ed. Yogyakarta: Pustaka Pelajar; 2011.

[5] F. Rigaux, "Hans Kelsen on International Law," Eur J Int Law. 329. 1998

[6] A. A. Aliyu, M. U. Bello, R. Kasim, \& D. Martin, "Positivist and Non-Positivist Paradigm in Social Science Research: Conflicting Paradigms or Perfect Partners?" Journal of Management and Sustainability, Vol. 4(3), 79,2014.

[7] M. S. Buana, "Living Adat Law, Indigenous Peoples, and the State Law: A Complex Map of Legal Pluralism in Indonesia." International Journal of Indonesian Studies, Vol. 1(3), 108, 2016.

[8] M. Healy, \& C. Perry, "Comprehensive Criteria to Judge Validity and Reliability of Qualitative Research Within the Realism Paradigm," Qualitative Market Research: An International Journal, Vol. 3(3), p. 121, 2000.

[9] E. Indarti, Diskresi dan Paradigma : Suatu Telaah Filsafat Hukum. Semarang: Badan Penerbit Undip; 2010.

[10] C. Kivunja, \& A. B. Kuyini, "Understanding and Applying Research Paradigms in Educational Contexts." International Journal of Higher Education, Vol. 6(5), 26-27, 2017.

[11] Z. Z. Mutaqin, "Indonesian Customary Law and European Colonialism: a Comparative Analysis on Adat Law." Journal of East Asia and International Law, Vol. 4(2), 352, 2011.

[12] Republika. Suku Anak Dalam Unjuk Rasa di PN Sarolangun. Jambi, Indonesia. (2009, March 02).

[13] F. Rigaux, "Hans Kelsen on International Law." European Journal of International Law, Vol. 329, 1998.

[14] J. Scotland, "Exploring the Philosophical Underpinnings of Research: Relating Ontology and Epistemology to The Methodology and Methods of The Scientific, Interpretive, and Critical Research Paradigms." Journal of English Language Teaching, Vol. 5(9), 10, 2012.

[15] G. F. Wanma, A. Salle, A. Saleng, \& A. M. Pide, "The Existence of Adat Law Community in Indonesian Legal Regulations." Journal of Law, Policy and Globalization, Vol. 39, 127, 2015.

[16] D. Yu. "Customary Law in The Practice of Criminal Law: A Real and Powerful Role." Peking University Law Journal, Vol. 36, 2013. 